\title{
Richard Cobden, the German States and the Zollverein
}

\author{
John R. Davis*
}

Richard Cobden's connections with Germany are less obvious in accounts of his life than with other countries. ${ }^{1}$ Cobden did not write about Germany specifically, in contrast with the United States and Russia. His negotiation of the Anglo-French commercial treaty of 1860 predominates in accounts of his relationship with Europe. The 39 German states of Cobden's day are unwieldy as a subject and far less photogenic than nation-states. Their fragmentation, as so often then and since, has produced a blind spot of sorts, with Cobden's Austrian activities dealt with separately to Prussia, for example. A different blind spot arises from the fact that Cobden was involved with the German states not just in political and economic senses, but in many different ways. Accounts, focusing since John Morley's biography mainly on Cobden's political activities, have not explained the striking fact that his 15-year-old son died in Heidelberg. The Free Trade Apostle Cobden's expressions of admiration for state-led reforms in Germany have been passed over rather in embarrassment. There has also been no explanation of Cobden's friendship and correspondence with Baron von Bunsen, the Prussian Ambassador to London, and one of the most significant players in Anglo-German cultural exchange in the $19^{\text {th }}$ century. Neither Cobden's attendance at the Peace Conference at Frankfort in 1850 nor his views on the Schleswig-Holstein dispute have been dealt with. However, any evaluation of Cobden's relationship to the German states must approach the subject in multidisciplinary and integrated fashion. Only in this way do connections and coherence become discernible.
\end{abstract}

In the German states, where commercial politics became dominated by Austro-Prussian rivalry and nationalism, British Free Trade, and with it Richard Cobden, took on an iconic importance. Suffice it to say that Cobden's high profile reception on his visit to Germany in 1847 can only really be understood when one takes into account that commercial policy had become a political battlefield in Germany by this time. ${ }^{2}$ Yet in the complementary sense of the role of the German states in Richard Cobden's life and thought, there is also an important story to tell. Cobden's early interest in Germany casts light on the Germanophilia of the early Victorians, particularly in the realms of culture and reform. Aspects of Cobden's German encounter tell us much about the world of the "cosmopolitan

* Prof. Dr. John R. Davis; The Faculty of Arts and Social Sciences, Kingston University (j.davis@kingston.ac.uk).

1 The only previous dedicated work on the subject is Trautz Fritz (1952), Richard Cobden's Associations with Germany, Reprinted from the "Bulletin of the John Rylands Library”, vol. 34, no 2 March 1852, Manchester, John Rylands Library, 1952.

2 Davis J. (1997): Britain and the German Zollverein, 1848-1866, Macmillan, Basingstoke, 1997. See also, for example, Kretzschmar A. (1846): Richard Cobden. Apostel der Handelsfreiheit, Comptoir, Grimma, 1846. 
bourgeoisie" of Manchester, the influx of German merchants and industrialists, and the impact they had on British culture. ${ }^{3}$ Cobden's views on Germany reveal his close connections with Benthamism, and cast light on the Germanophilia typical of that movement, and show him less as an innovator in political and economic thought. With regards to the Zollverein, the customs union set up by Prussia in 1834, Cobden's arguments reflect the centrality of that organisation to Benthamite support for Free Trade. His observations on German commercial policy afterwards, however, reveal the position of hopeful watchfulness British liberals were forced - or forced themselves - to adopt regarding German industrialisation. The detail, scope and candour with which Cobden recorded his travels in Germany make them unusual and valuable as a historical record. There is a particular value to German history in the travelogue of 1847 , as it throws light on the views of prominent politicians of the Vormärz, but also important swathes of the influential class of merchants and commercial politicians - a class which would grow in significance from 1850 onwards. Cobden's German travel diaries of 1838 however also offer unique insight into German history and the Anglo-German cultural encounter. ${ }^{4}$

Much evidence suggests that, like many others early Victorians, Cobden was influenced by a general cultural Germanophilia. Gothicism and Romanticism had both directed attention to Germany before 1800 . The Napoleonic wars, however, prevented travel to the Continent and strengthened antipathy to German Sturm und Drang culture. Still, a small group of intellectuals and writers remained in touch with German developments, particularly in the realms of philosophy and literature. The British alliance with Prussia and Austria, peace in 1815, and antipathy towards French culture, turned this into a flood of interest in German literature, philosophy and learning. Many people were convinced by Madame de Staël's image of Germany as the "land of ideas" in her De L'Allemagne. Lord Byron's association of Germany with Romanticism and heroism in his Childe Harold also had a deep and popular impact. By the 1830s, journals were dominated by reviews of German work, particularly in philosophy and theology. A knowledge of German culture had become a badge of learning; the German professor a lasting stereotype in Britain.

That Cobden had read Byron is certain. Morley has him buying a copy with his first earnings in 1819, and he quoted him extensively during his tour of the Mediterranean in 1836-37. ${ }^{5}$ As an autodidact, and a man seeking to improve himself and prove his knowledge, it would have been impossible for Cobden to escape the general respect paid to German scholarship in Britain. In particular, as a Broad Church Anglican, he could not have overlooked the bitter controversies caused within Anglicanism by German theology, controversies which engaged wide circles of the intelligentsia and had ramifications outside religion due to the fact that in England, at least, academics till this time were generally clerics; and graduates, Anglican. On one of the few occasions that Cobden expressed his personal beliefs his views appear strongly Hegelian. Writing to George Combe in 1846, he stated that "With reference...to your remarks as to the evangelical dissenters and religionists generally, and their views of your philosophy of morals - I will confess to you that I am not inclined to quarrel with that class of my countrymen. I see the full force of what you urge, but am inclined to hope more from them in time than any other party in the State. Gradually and imperceptibly to themselves they are catching the spirit of the age, so far as to recognize the moral laws as a part of our natural organization. They do not accept your views to the superseding of their own, but, like geology, your science is forcing its way

3 Jones Charles, A. (1987): International Business in the Nineteenth Century. The Rise and Fall of a Cosmopolitan Bourgeoisie, Wheatsheaf, Brighton, 1987.

4 Contained in Cobden Papers 451, W.S.R.O. Now published as John R. Davis (ed.), Richard Cobden's German Diaries, Saur, Munich, 2007.

5 Morley John (1881): Life of Richard Cobden, Chapman and Hall, London, 1881, volume 1, p6. 
alongside of preconceived ideas, and they will for a time go together without perceptibly clashing."

These lines, with their strongly Hegelian, even Straussian flavour, were written in the same year as George Eliot's translation of Strauss' Leben Jesu. The idea that religions evolved was, and was perceived as, Germanic, and was widely shared in Britain by Broad Church figures such as F.D. Maurice of the Christian Socialists, and by nonconformists, unitarians and German immigrant merchants in Manchester. It was also a view of things promoted prominently by Bunsen in his religious works, and possibly helped underpin Cobden's relationship with the Prussian Ambassador. Similar, Kantian influences upon Cobden are also to be discerned. ${ }^{7}$

A particularly Germanophile group in the 1830s, however, was the circle of reformers known loosely as the Benthamites. With strong links with nonconformism and freethinking, and overlapping with circles interested in German culture, the Benthamites, mainly interested in state reform, shared a view of the superiority of German learning. This was reflected in the project to found University College, London, in 1826, modelled on Wilhelm von Humboldt's idea of a university based on research and Faculties rather than moral instruction and religion. It brought together Jeremy Bentham, James Mill, John and Sarah Austin, Henry Crabb Robinson as well as two descendants of German emigrés, George Grote - which whom Cobden corresponded - and Alexander Baring. The Benthamites were also, however, attracted to the Hegelian use of the Prussian state to bring about improvements in the economy and society. Close attention was paid to the German states' reforms. Beginning with Edwin Chadwick's Poor Law Commission in 1834, and lasting until and beyond discussion of the welfare state in the 1890s, it was traditional for reformers to look first of all at what was happening in Prussia and, to lesser extent, the other German states too. ${ }^{8}$

The two sides of Benthamite interest in Germany - the cultural and the Hegelian came together in the issue of popular education in the 1830s. Sarah Austin's translation in 1834 of Victor Cousin's Report on the State of Public Instruction in Prussia extended Benthamite interest from universities to primary schools, and began an obsession in Britain with German educational lasting well into the $20^{\text {th }}$ century. For many reformers, including Cobden, Prussian schools offered a model of secular, modern, state-directed education contrasting positively with the religious and Classics-based British system. ${ }^{9}$

The Benthamites also became interested in the Zollverein, however, after its foundation in 1834. Before Cobden and Bright transformed the battle for Free Trade by giving it social, moral and idealistic dimensions, the Benthamites were campaigning for it on the grounds of economic theory. Britain's tariffs, they believed, were counterproductive, in that they prevented agricultural countries exporting to Britain to pay for industrial imports, and thereby encouraged foreign manufacturers to develop. The Zollverein, they argued, provided evidence that foreign countries were beginning to set themselves up against Britain as competitors. These were the arguments put forward by the Anti-Corn Law Association, founded in 1836 by George Grote, William Molesworth and others.

6 Morley, 1881, p200.

7 See Farrar P. N. (1987): Richard Cobden. Educationist, Economist and Statesman, D.Phil Thesis, Sheffield, 1987, $\mathrm{p} 36$.

8 Burns A. and Innes J. (2003): Rethinking the Age of Reform, Cambridge University Press, Cambridge, 2003, pp11-15.

9 See Farrar, 1987, pp49-51. 
It is against this backdrop that Cobden's first visit to Germany in August 1838 might be understood. Cobden appears to have combined several objectives at once with his visit. ${ }^{10}$ On the one hand, he went partly in consequence of its attraction culturally. But he also - and like many others - wished to study at first hand the state which was attracting so much attention among reformers - Prussia. Cobden's first political campaigning in the early 1830s revolved around the issue of popular education. That he shared the Benthamites' admiration of state-led reforms, particularly in education, is obvious from his letter to the publisher William Tait, written shortly before his departure: 'Do not,' he wrote "let your zeal for the cause of democracy deceive you as to the fact of the opaque ignorance in which the great bulk of the people of England are wrapt. If you write for the masses politically, and write soundly and honestly, they will not be able at present to appreciate you, and consequently will not support you... There is no remedy for all this but improved education...The great body of the English peasants are not a jot advanced in intellect since the days of their Saxon ${ }^{11}$ ancestors. I hope you will join us in a cry for schoolmasters as a first step to Radicalism.... have unbounded faith in the people, and would risk universal suffrage to-morrow in preference to the present franchise. But we shall never obtain even an approach towards such a change, except by one of two paths - Revolution or the Schoolhouse." $" 12$

In 1837, in London, Cobden had come into contact with Benthamites, including, notably, Henry Cole, Grote, Molesworth, and another concerned with German commerce, John Bowring. ${ }^{13}$ He shared their positive appreciation of Prussian reforms and education. ${ }^{14}$ He was also sensitised by them, as well as by his contact with northern manufacturers, to the issue of German commercial competition.

However, it is interesting that, once in Germany, rather than seeing industrialisation as minor problem to be alleviated by Free Trade in Britain, Cobden appears to have been immediately struck by the potential for unification under Prussia. Writing to his brother, Frederick, he described how "Although a very rapid one, my journey has given me a better insight into German character and the prospects of central Europe than I could have ever gained from the eyes of others. Prussia must be looked upon as a rising state, whose greatness will be based upon the Commercial League [the Zollverein]... The effect of the League must inevitably be to throw the preponderating influence over thirty millions of people into the hands of the Cabinet of Berlin. By the terms of the Union, the money is to be collected and paid by Prussia; a very little financial skill will thus very easily make the smaller states the pensioners of the paymaster. Already, I am told, Prussia has been playing this game; she is said to be two millions of dollars a year out of pocket by her office, owing to her having guaranteed the smaller partners certain amounts of revenue. Besides the power that such a post of treasurer will confer on Prussia, other causes must tend to weaken the influence of the lesser states' governments. A common standard of weights and measures, as well as of money, is preparing, and these being assimilated, and the revenue from Prussia, whose literature and modes will become the standard for the other portions of Germany, what shall prevent this entire family of one common language, and possessing

10 For the full text of Cobden's travel diaries see Davis J. R. (2007): Richard Cobden's German Diaries, 2007.

11 The rising interest in German scholarship, particularly in philology and the works of Jakob Grimm, encouraged notions of common Anglo-German ancestry, rooted in Saxon culture. Cobden appears to echo this here. See Dockhorn Klaus (1950): Der deutscher Historismus in England, Vandenhoek und Ruprecht, Göttingen, 1950, Chapter 5.

12 Morley, 1881, p127.

13 Morley, 1881, p135 and p214.

14 For more on Cobden's admiration of Prussian education, see Hinde Wendy (1987): Richard Cobden. A Victorian Outsider, Yale University Press, New Haven and London, 1987, pp53-5. 
perfect freedom of intercourse, from merging into one nation? In fact they are substantially one nation now, and their remaining subdivisions will become by-and-by only imaginary; and some Radicals will hereafter propose, as we have done in Manchester, to get rid of the antiquated boundaries of the townships of Hesse, Oldenburg, etc., and place the whole under one Common Council at Berlin. There are heads in Berlin which have well reflected upon this, and their measures will not disappoint their country." 15

Cobden, in fact, showed the typical ambivalence of British Free Traders towards the Zollverein, which, while it made protective tariffs possible, also constituted a major step forward in terms of economic reform and modernisation in Central Europe.

The Germanophilia of reformers radiates through Cobden's descriptions while in Germany at this time and explains his gushing admiration for a country viewed by other liberals as despotic. "I very much suspect," he wrote "that at present, for the great mass of the people, Prussia possesses the best government in Europe. I would gladly give up my taste for talking politics to secure such a state of things in England. Had our people such a simple and economical government, so deeply imbued with justice to all, and aiming so constantly to elevate mentally and morally its population, how much better would it be for the twelve or fifteen millions in the British Empire, who, while they possess no electoral rights, are yet persuaded they are freemen, and who are mystified into the notion that they are not political bondmen, by that great juggle of the "English Constitution" - a thing of monopolies, and Church-craft, and sinecures, armorial hocus-pocus, primogeniture, and pageantry! The Government of Prussia is the mildest phase in which absolutism ever presented itself. The king, a good and just man, has, by pursuing a systematic course of popular education, shattered the sceptre of despotism even in his own hand, and has for ever prevented his successors from gathering up the fragments...You have sometimes wondered what becomes of the thousands of learned men who continually pass from the German universities, whilst so few enter upon mercantile pursuits. Such men hold all the official and Government appointments; and they do not require 10001 a year to be respectable or respected in Prussia. Habits of ostentatious expenditure are not respectable there. The king dines at two, rides in a plain carriage, without soldiers or attendants, and dresses in a kind of soldier's relief cap. The plays begin at six and close at nine, and all the world goes to bed at ten or eleven." 16

Cobden's admiration for Prussia here is only explicable when one considers his closeness to Benthamism at this point. By the 1880s, when Prussia had become synonymous with military victory and Bismarckian conservativism, it was felt so embarrassing that John Morley was forced to apologise for it. "It is to be remembered in reading this," Morley wrote in 1881 "that it was written forty years ago. Not a few considerate observers even now hold that the prospect of German progress which Cobden sketches, would have been happily realized, if Prussian statesmen of a bad school had not interrupted the working of orderly forces by a policy of military violence which precipitated unity, it is true, but at a cost to the best causes in Germany and Europe, for which unity, artificial and unstable as it now is, can be no worthy recompense. As for the contempt which the passage breathes for the English constitution, it is easy to understand the disgust which a statesman with the fervour of his prime upon him, and with an understanding at once too sincere and too strong to be satisfied with conventional shibboleths, might well feel alike for the hypocrisy and the shiftlessness of a system, that behind the artfully painted mask of popular representation concealed the clumsy machinery

1511 September 1838, Morley, 1881, p128.

1611 September 1838, Morley, 1881, p128. 
of a rather dull plutocracy. It is not right to press the phrases of the hasty letter of a traveller too closely.",17

However, Morley's apology covered over the fact that Cobden, like many others, admired greatly what was being done in the name of reform in Germany, and saw in Prussia the most promising vehicle for change.

Meanwhile, Cobden's letters to his sister in Manchester from Berlin reflect his awareness of Germany as both a rather fashionable tourist destination and a place associated with tantalisingly scandalous religious liberalism. There are descriptions of the Tivoli gardens, sightings of the royal family, and the social hustle and bustle of a German Sunday in comparison with an English sabbath. However, another thing which struck Cobden during his visit to Berlin, was the engagement of manufacturers there in political questions. As he wrote to his sister "It humiliates me to think of the class of people at home, who belong to the order of intelligent and educated men that I see on the Continent, following the business of manufacturing, spinning, etc. Our countrymen, if they were possessed of a little of the mind of the merchants and manufacturers of Frankfort, Chemnitz, Elberfeld, etc., would become the De Medicis, and Fuggers, and De Witts of England, instead of glorying in being the toadies of a clod-pole aristocracy, only less enlightened than themselves." 18

The image of German producers engaging themselves in questions of government and commercial politics inspired Cobden at a crucial moment in his career. It was on his return to Britain in the autumn of 1838 that he became involved in commercial politics and the foundation of the Anti-Corn Law League. Cobden's information about economic developments in the German states - carefully recorded in his travel diaries - now also became highly useful. John Bowring had impressed on Manchester manufacturers the economic threat developing in the Zollverein during a talk in the city in September $1838 .{ }^{19}$ Bowing would confer with Cobden after his own visit to the German states in another visit to Manchester in 1839, shortly before his Report to the Select Committee on Foreign Trade in $1840 .{ }^{20}$ During the debate on Bowring's Report in Parliament in 1841, Cobden supported Bowring's argument that protection was encouraging German competition into being. ${ }^{21}$ Cobden, now the "knowledgeable critic," 22 began using information about German industry and commerce in lobbying for Free Trade. He drew on commercial developments in Germany to prove his points in speeches and petitions. In Parliament he compared the Anti-Corn Law League to the Hanse Towns, which in his view had promoted commercial liberalism there against the feudalism of the German interior. ${ }^{23}$

In 1840, Cobden returned again to Germany on his honeymoon. This time fashion and tourism were prominent features of his visit. The main destination was Switzerland a place made increasingly attractive by the Romantics, and the subject of a book by Wordsworth several years before. Cobden possibly hoped to make his honeymoon more than a romantic event and to inspect further a country he had visited briefly in 1834. At that time he had written that "The people of this country are I believe the best governed and therefore the most prosperous and happy in the world. It is the only Government which has

17 Morley, 1881, p131.

183 September 1838, Morley, 1881, p134.

19 Read Donald (1967): Cobden and Bright. A Victorian Political Partnership, Edward Arnold, London, 1967, pp21-2.

20 Morley, 1881, p151.

2125 August 1841, Parliamentary Debates, 59, August-October 1841.

22 Edsall Nicholas C. (1986): Richard Cobden. Independent Radical, Harvard University Press, London, 1986, p19.

23 Morley, 1881, p149. 
not one douanier in its pay, and yet, thanks to free trade, there is scarcely any branch of manufacturing industry which does not in one part or other of the country find a healthy occupation. The farmers are substantial. Here is a far more elevated character of husbandry life than I expected to see. Enormous farm-houses and barns; plenty of out-houses of every kind; and the horses and cows are superior to those of the English farmers...."24

How far Switzerland influenced Cobden's views on Free Trade is a subject which sadly can only be hinted at here. Anyway, because it was their honeymoon, Cobden's diary entries, it has been noted, showed "signs of haste or, possibly, boredom." ${ }^{25}$ However, his travel along and across the border between Switzerland and the German state of Baden, where he 'saw the custom house officers with guns in hand walking along on the German side to prevent smuggling from Switzerland,' caused pause for thought, and reinforced observations on the comparatively superior state of Swiss agriculture. ${ }^{26}$

Cobden's visit to the German states on the way home followed a conventional route down the Rhine made popular by the Grand Tour, and now visited by increasing numbers inspired by Byron's Harold as well as by numerous pictorial works and travelogues. A stop in July in Wiesbaden at the spas was reflected the influence of works such as Augustus Bozzi Granville's The Spas of Germany (1837). They "looked in a little at the gambling table at the Cursaal," and "drank hot water tasting like chicken broth" and "bathed in the same kind of water..."27 Incidentally, James Johnson's Pilgrimages to the Spas (1841) noted Wiesbaden's Cursaal as "the most magnificent in Europe," and also verified that "the water looks rather of a greenish-yellow colour, and seems turbid in the well, with a scum over a part of it, which is called "cream," and is considered by the chemists as a peculiar animal or extractive matter, whose nature and source are unknown. The taste is that of weak chicken-broth with rather too much salt." ${ }^{, 28}$ As often when in Germany, Cobden commented often upon the sense of safety and social harmony in German cities and, making a short journey up the Main, decided that "Frankfurt is decidedly one of the prettiest towns in Europe \& cleanliness itself in the principal streets." However, in some quarters, he noted, this was not so: "the jews in particular are very much neglected." 29 Cobden, like many other British visitors, was appalled by the German treatment and ghettoisation of Jews.

Cobden's next visit to Germany was as part of his continental tour of 1846-47. Looking for rest after the successful battles over the Corn Laws, his European tour was also a conscious attempt to achieve commercial liberalisation abroad. Yet in France, and especially in the German states, commercial liberalisation had become a major political concern; and Cobden, as a consequence of his victory in Britain, a figurehead of the movement. Any idea that he might take things at his own pace were trounced as meetings were convened and huge numbers gathered to take part in long banquets with much speechifying. The thirst with which Germans in particular sought Cobden's presence explains his continual pleas for rest and privacy throughout his trip there.

It was significant that Cobden entered the German states this time from Italy, for this allowed him an insight into the injustices of Austrian rule there, possibly leaving an indelible antipathy towards Austria in his mind. After one banquet in Milan in June 1847,

246 June 1834, Morley, 1881, p28.

25 Rogers Jean Scott (1990): Cobden and His Kate. The Story of a Marriage, Historical Publications, London, 1990, p15. See the Journal of a Tour through Switzerland, Cobden Papers 441, W.S.R.O.

264 July 1840, Cobden Papers 441, W.S.R.O.

27 Rogers, 1990, p18.

28 Johnson, 1841, p50.

2921 July 1840, Cobden Papers 441, W.S.R.O. 
Cobden recorded in his diary that "Before the dinner was concluded, other orators, who had become a little heated with wine, wished to speak. One of them broke through the rule laid down, and almost entered upon the forbidden ground of Austrian politics. However, by dint of management and entreaty the excited spirits were calmed, and the banquet went off pretty well. Received an anonymous letter entreating me not to propose the health of the Emperor of Austria." 30

Several weeks later, in the Austrian port of Trieste, Cobden recorded that he had "Dined at a public dinner given to me by about ninety of the principal merchants in the saloon of the theatre. M. Schläpfer, president of the Exchange Committee, in the chair. The speeches were delivered in the midst of the dinner. M. De Bruck, the projector and chief director of Austrian Lloyd's spoke well. Signor Dell' Ongaro, who is an Italian and a poet, read a speech, in which he made allusion to Italian nationality, which drew forth some hasty remarks from M. De Bruck, and led to a scene of some excitement. After dinner I persuaded them to shake hands..."31

Cobden's pacific services were therefore already being utilised in the heated realms of German politics.

Cobden's comments on Austria as he passed through the country, meanwhile, betray a much less glowing opinion than of Prussia. The contrast with Italy, the overtly rural, Catholic character of Austrian society - Cobden's Protestantism as a factor in his German sympathies is a subject to be dealt with below - and Cobden's ire at Austria's highly protectionist economy, all seem to have played a part. His interview with Prince Metternich, Austria's Chancellor, soon to be deposed and exiled to Britain, did not improve things. Metternich, he recorded in his diary, 'talks incessantly, perhaps in order to choose his own topics,' refused representative government in Austria on the grounds that its ethnic minorities would not be able to speak to one another, and - perhaps worst of all where Cobden was concerned - attempted to ingratiate himself by arguing that Britain and Austria had a natural affinity by dint of their common hatred of France and need to cooperate within the European balance of power. "He is probably the last of those state physicians," Cobden concluded, "who looking only to the symptoms of a nation content themselves with superficial remedies from day to day, \& never attempt to probe beneath the surface to discover the source of the evils which afflict the social system. This order of statesmen will pass away with him, because too much light has been shed upon the laboratory of governments to allow them to impose upon mankind with the old formulas." ${ }^{32}$

Cobden's tour took him from Vienna to Prague, Dresden, Berlin, and the Baltic Ports. On his return from Russia he would pass back through the Baltic Ports to Hamburg, crossing Holstein, an area he was to have much to do with later. Cobden was highly unusual in being able to mix freely with aristocrats, middle-classes and industrialists. This privilege was not accorded to tourists or diplomats, who had relatively limited social spheres. For historians, this makes his commentary a vital record of events. For Cobden, it provided a wealth of information on German politics and economics arguably unmatched in Britain. Apart from Metternich, he also met the King of Prussia as well as his brother and successor, Wilhelm, the Austrian and Prussian Ministers of Finance, and also significant figures in the turbulent world of German commercial politics such as the Viennese Professor of Economics, Franz Neumann, the English-born Prussian Free Trader, John Prince Smith, and the Director of the Prussian Bureau of Statistics, Karl Dieterici. He also met many prominent German manufacturers, including Gustav Harkort. It is fascinating to ponder

30 Morley, 1881, p439.

31 Morley, 1881, p441.

32 Taylor Miles (1994): The European Diaries of Richard Cobden, 1846-1849, Scolar, Aldershot, 1994, p154. 
that the M. De Bruck he mentioned at the meeting in Trieste would later become the Austrian Minister of Trade and propose a giant German customs union - a 70-Millionenreich - stretching from the Baltic to the Mediterranean. Had this come to pass, political developments and the course of industrialisation in $19^{\text {th }}$ century Europe might have looked quite different. Many others Cobden mentions became significant political players after the revolutions of 1848 , as reactionary regimes reached out an olive-branch to industrialists. The trip meanwhile also brought him into contact with major British experts on Germany, in particular the Consuls General - Colonel Hodges at Hamburg, and John Ward at Leipzig. His frequent encounters with British engineers, entrepreneurs and merchants repeatedly reminded him of the extent of British trade with the German states in contrast with other areas.

While in Germany Cobden was able to learn much about Friedrich List, who had only died in 1846, from people who had known him personally. His diary suggests a particularly keen interest on this front, though, as in most respects, the tone is narrative rather than offering commentary or judgement. ${ }^{33}$ obden was also able to get a far more detailed picture of the history of the Zollverein, the balance of economic interests within the German states, and the likelihood of commercial liberalism. On the Zollverein, like the British government itself, Cobden appeared to accept that the organisation had started with liberal intentions, and in fact represented a great step forward in terms of the commercial integration of the German states and the easing of trade across Europe. His earlier positive attitude towards Prussia was backed up by his recurring observations that protectionism was being fostered in the south of Germany. Yet Cobden's diary also contains a record of all the interests damaged in Germany by protectionism, as if arming himself with evidence for future battles.

At the outset of Cobden's tour, in July 1846, he wrote to his friend Salis Schwabe that "With God's blessing, I will see all the leading potentates and statesmen of Europe. I will be an ambassador from the Free-traders of England to the governments of the great nations of the Continent. But we must be profoundly secret upon this subject. If it were known that I started with any such design of propagandism, all the protectionists and smugglers would be plotting to thwart me, or, perhaps, some of the latter might shoot us on our way to Madrid."${ }^{\prime 34}$ It is interesting, however, that he recorded while in Berlin that he had written to Dr Asher - owner of the Hamburg-Berlin railway - "declining his invitation to address a party of free-traders \& expressing my determination not to interfere in the domestic concerns of Prussia." ${ }^{35}$ Was this a ruse, to deflect suspicions of his motives, or to get out of another tedious banquet? Or had Cobden, by this point, realised that any attempt to promote Free Trade by a Briton in Germany would be counterproductive? One suspects it was the latter. This was certainly the conclusion of the British government on the subject, which went over after 1846 to a position of watchfulness regarding German commerce. Cobden, in fact, seems to have lost interest in lobbying for Free Trade abroad after his German visit.

A point easy to overlook about Cobden's 1847 tour was that he still managed to combine cultural events with business. In Vienna, he and Kate visited the Belvedere gallery and particularly noted the Dürer paintings. They also visited the art galleries of Dresden and Berlin. ${ }^{36}$ By this point, the art establishments of the German states had achieved prominence in Britain, particularly among art education reformers. Dürer, particularly, was admired for his technical excellence. One of the foremost promoters of German art was Anna Jameson, whose Sketches of Germany. Art-Literature - Character was published in

33 See Taylor, 1994, p162.

34 Schwabe J. Salis (1895): Reminiscences of Richard Cobden, Fisher Unwin, London, 1895, p1.

35 Taylor, 1994, p167.

36 Taylor, 1994, p166. 
1837, inspiring many Victorians to "do" the German galleries. Cobden, coincidentally perhaps, had met Jameson while in Rome, and had gone with her round the Vatican. ${ }^{37} \mathrm{He}$ described her as "an agreeable woman, whose good-nature and sense prevent her from displaying the unpleasant qualities of too many literary ladies. ${ }^{38}$ A more respected guide to European art could not have been had for any price at that time.

In Berlin, as in 1838, Cobden particularly noted the freer religious air of Berlin. "The Sunday is kept in this protestant capital similarly to the catholic cities on the continent," he wrote, "the opera \& theatres are opened; the bourgoisie go in crowds in the evenings to gardens where good music, \& other amusements are going on; parties sit at little tables with tall glasses of pale beer before them from which the men \& sometimes the women sip, the former generally smoking their cigars \& the latter knitting - families may be seen in the environs of the city sitting in their little gardens before their houses playing cards, or dominoes, or the men smoking \& the women knitting - in the evening they frequently sup in the same places - the shops are generally closed, and all business is suspended." 39

German smoking, by the bye, was a particular bug-bear of Cobden's during his visit. In Austria he would refer to the men "always smoking their grotesque pipes." ${ }^{, 4}$ In Lübeck, in September, he referred to a visit to the Town Hall beer-cellar, where he was "enveloped in clouds of smoke" and described the place as "a midnight scene in a "coal-hole".," In this, however, Cobden was unconsciously recording a cultural difference noted by many other British travellers, who also recoiled in horror from smoking. In Douglas Jerrold's Shilling Magazine, a traveller to Prussia in 1845 observed "Well, here is a whole nation of constant smokers! Many gentlemen appear to have the pipes in their mouths during at least one-half of the day, and the majority of the peasantry the whole day. The labourers in the fields have all their pipes in their mouths while at work, and these pipes are only laid down a minute upon great occasions and emergencies requiring the highest efforts...One can regard it in no other light than a national mania." 42

Cobden's trips to Germany allowed his arguments on that subject, and upon Free Trade abroad, to be both persuasive and informed, and as German culture had become generally admired, they also no doubt raised his standing socially. But Cobden's travels also meant he became more engaged than most of his compatriots with German affairs subsequently. As the revolutions swept across Europe in 1848, Cobden, unlike other liberals, felt that "Spite of present appearances, I see no reason to doubt that in the end the mass of the people will rise a peg or two in the scale in consequence of the present movement. In Germany, the restrictions on the press can never be reimposed, \& with the freedom of "unlicensed printing" that people will make good their ground against kings \& princes. ${ }^{\circ 3}$ As the forces of reaction closed in in 1849 , Cobden once more threw himself into opposing them, particularly directing his energies against Austria. Cobden led a prominent campaign in 1849 to oppose Austrian efforts to raise money on the London markets in order to finance its activities. Britons, he stated, should "raise their voice in condemnation...of the system by which Austria and the other powers maintain their enormous armies and carry war and destruction not only into their own provinces but into

37 Taylor, 1994, p101

38 Rogers, 1990, p63.

39 Taylor, 1994, p167.

40 Taylor, 1994, p151.

41 Morley, 1881, p463.

42 Douglas Jerrold's Shilling Magazine, 1845, 2, p151.

4312 October 1848, Richard Cobden to John Bright, Add MSS 43649, British Library. 
the territories of their neighbours. ${ }^{" 44}$ He campaigned energetically for public support for Hungarian refugees, helping raise money for them and arranging their exile to the USA. In opposing Austrian reaction, Cobden came close to the position of most British liberals, including Lord Palmerston, the foreign secretary. However, Cobden's other principles made him cautious. As he wrote John Cassell around this time, "beware how you commit the liberal party to the principle by our government of intervention in support of Hungary \& Rome (why not also Venice \& Lombardy?) For if the liberal press takes that line adieu to all prospects of reducing our warlike establishments." 45

Shortly after, Cobden also became involved with the Schleswig-Holstein dispute where friction between Danish and German nationalists led to conflict. The second International Peace Conference was held in Frankfurt in August 1850, in the church where, two years previously, German revolutionaries had gathered. This afforded Cobden a further view into the state of German politics. When Lord Palmerston backed up Russia in forcing Prussia to withdraw from Schleswig-Holstein, Cobden's anti-interventionist principles, as well as his pro-Prussian sympathies, were activated. To John Cassell he wrote that "I had good opportunity, whilst at Frankfort, of learning the opinions of the people of Germany upon the conduct of our government in the Schleswick-Holstein affair. There is but one feeling of indignation amongst the liberal constitutional party at the alliance which England has formed with Russia \& France - indignation not unmixed with sorrow, for they had fondly hoped that they possessed the sympathy \& friendship of the English people. Now if there be a nation on the Continent with which we might fairly expect to maintain an amicable feeling it is Germany. Especially liberal Protestant Germany \& it is precisely the latter portion of that empire which we have alienated from us by our intervention in the Schleswick-Holstein affair. What end have we to gain by our protocols to compensate for the loss of the German heart which is the heart of Europe? In my opinion there never was a greater mistake than in attributing to Lord Palmerston liberal or democratic objects in his continental interventions - what possible good can popular self-government gain from this junction of England with Russia? It is only setting up that barbarous power in western Europe, \& arming her with increased influence to be used in the cause of despotism..."46

While at the Peace Conference, however, Cobden had given a speech supporting a new mode of conducting international affairs through arbitration. As John Morley explained, Cobden "was too practical to dream that regard for purely moral opinion could be trusted to check the overbearing impulse of powerful selfish interests. Wars, however, constantly arise not from the irreconcilable clashing of great interests of this kind, but from mismanaged trifles. ${ }^{, 47}$ Cobden called on the British government to act as mediator, in order to compensate the Danish government for loss of rights over Schleswig-Holstein and allow Germans there self-rule. The idea of using arbitration to reform old treaties was one supported by Bunsen, who wrote to Cobden expressing "how much I feel obliged to you, as a German and as a citizen of the world, for all you said \& did at Frankfurt. I can assure you that your speech gave satisfaction and unmixed pleasure to all with whom I aim to converse of those subjects so dear to every German patriot and philanthropist. I admire every word of your speech, and I believe there will be a blessing upon it." ${ }^{48}$ Cobden immediately set about supporting his proposal in practice, collaborating with Baron Bunsen in seeking to bring Prussia and Denmark to the negotiating table. Cobden foresaw the issue being submitted to

4429 May 1849, Richard Cobden to E. Fry, Richard Cobden Papers MS43668.

454 September 1849, Richard Cobden to John Cassell, Add MSS 43668, British Library.

465 September 1850, Add MSS 43668, British Library.

47 Morley, 1881, p530.

482 October 1850, Add MSS MS43668, British Library. 
an international jury, ${ }^{49}$ not unlike the one instituted some months later for the Great Exhibition, a project in which both he and Bunsen took leading parts. Unfortunately for both of them, Lord Palmerston, who stepped in to offer British mediation, had more traditional ideas of arbitration.

Cobden's engagement with German politics continued during the 1850s. In 1851, he voiced his frustration at his fellow Britons' lack of interest in the political clamp-down in Hessen-Kassel. Telling a German acquaintance to write a factual account of the subject "such as a German would write for the use of a child," he explained "for the English are as ignorant as children on everything relating to German affairs. ${ }^{~}{ }^{50}$ At the time of the Crimean War, when the German states suffered vitriolic press criticism for their neutrality, Cobden followed carefully through his German contacts the reality of the situation, and drew encouragement from it. To John Bright he wrote in July 1855 that "My Prussian friend Faucher has just called. He says that press in Germany is more \& more against England \& France, - not for Russia however. But the democratic papers, he says, have laid hold of Johnny's and Palmerston's declarations against a war of nationality \& liberty, \& are denouncing it as a "diplomatic war." - The Conservative papers go against us in recounting our abuse of the Prussian policy. So that we have no friends there. He says there are busy doings at Vienna and Berlin - all sides trying to unite Germany in the interest of peace, \& that he expects other proposals for a settlement. It will very likely turn out as I remember I mentioned last October or November in a letter to you it would probably do - that after both sides have exhausted themselves at Sebastopol without any great success to either part, united Germany will step in \& insist on terms of peace..."

In 1859, when war between Austria and France appeared imminent over Italy, Cobden took the opportunity of calling upon the Austrian Ambassador to lecture him on the expediency of pulling out of Italy, and suggested the Austrians accept a financial indemnity for giving up Venetia. ${ }^{52}$

In 1864, Cobden led the Parliamentary opposition to intervention in the revived Schleswig-Holstein dispute. Such intervention, he believed on principle, would be counterproductive. There were grave financial implications to British trade, not least through any interruption with the German market. As Cobden reminded Gladstone and the Board of Trade, the USA might also exploit Britain's situation by coming to Germany's defence. ${ }^{53}$ War in Europe could no longer be localised, and Britain's global trade would not bear it. However, Cobden also based his position on his knowledge of the area, held to his position of 1850 that Schleswig-Holstein, essentially, was German, and saw the Danish claims as dynastic and based upon the balance of power and thus outmoded. As he told Parliament "In 1852...by the mischievous activity of our Foreign Office, seven diplomatists were brought round a green table in London to settle the destinies of a million of people in the two provinces of Schleswig and Holstein, without the slightest reference to the wants and wishes or the tendencies or the interests of that people... Kings, Emperors, Princes were represented at that meeting, but the people had not the slightest voice or right in the matter. They settled the treaty, the object of which was to draw closer the bonds between those two provinces and Denmark. The tendency of the great majority of the people of those provinces - about a million of them altogether - was altogether in the direction of

49 Salis Schwabe, 1895, p114.

506 August 1851, Richard Cobden to Julie Salis Schwabe, Julie Salis Schwabe, Richard Cobden. Notes sur ses voyages, Librairie Guillaumin, Paris, 1879, p175, [translated by the author].

5114 July 1855, Richard Cobden to John Bright, Add. MSS 43650, British Library.

52 Morley, 1881, p736.

5328 January 1864, Richard Cobden to John Bright, Add. MSS 43652, British Library. 
Germany. From that time to this year the treaty was followed by constant agitation and discord; two wars have sprung out of it, and it has ended in the treaty being torn to pieces by two of the Governments who were prominent parties to the treaty." 54

Cobden's last visit to Germany took place in 1855, when he accompanied his son, Richard - or Dick - to school in Heidelberg. Why Cobden should send his son to school in Germany is a subject touching on several aspects already mentioned, but also necessitating consideration of Anglo-German cultural contacts and the formation of German merchant communities in several British towns and cities. Cobden's own schooling probably predisposed him to alternative methods of teaching. His stay at Bowes Hall in Yorkshire, is described as "a grim and desolate time, of which he could never afterwards endure to speak," and as a forerunner of Dickens' Dotheboys Hall in Nicholas Nickelby. ${ }^{55} \mathrm{He}$ became, as mentioned, an ardent supporter of educational reform, and, especially after Sarah Austin's book on the subject in 1834, many reformers felt German education was superior. Dickens, himself a prominent supporter of German educational systems, wrote in Household Words " "Go into any Prussian town, or village, a little before eight o'clock, some December morning. The iron grasp of an imaginary duty has dragged all the children out of bed, washed them, and given them their breakfasts; and here they all are, turned out into the raw frost, all running to one point - the school!!... Whereas, go into any great English town, go into London as the greatest of 'em all. What do you find there? Freedom! Go down into Westminster, or up into Whitechapel. There you'll find the young Bricks, by thousands upon thousands, left to themselves from the moment when they are first able to crawl, and herding and growing together, in the gamest manner, like so many wolves." 57

Reformers' admiration for German educational methods encouraged Britons to go to school in Germany. Dickens' collaborator on Household Words, Henry Morley, had attended a Moravian school at Nieuwied, in Germany. The author, George Meredith, attended the same school somewhat later. Morley would send his own son to another school at Hofwyl, in Berne. G. H. Lewes, George Eliot's lover, sent his sons to the same school.

The rising profile of German education in Britain created an opportunity for employment for German governesses, tutors and educationalists. They, and enlightened German educational methods such as those advanced by Pestalozzi and Froebel, were also promoted by the large numbers of influential German merchants building up in manufacturing towns. ${ }^{58}$ In Manchester, this included figures such as Henry Simon, Friedrich Engels (working for his father's company, Emen and Engels), the Behrens family, Heinrich Siemens, Heinrich Leo, and the two Schwabe families. Many of Cobden's social circle were German. Many of them, including many of his British friends, employed German governesses. Julie Schwabe, for example, employed the formidable German socialist, educationalist and authoress Malwida von Meysenbug as governess, and was herself one of the most important promoters of Froebelian methods. ${ }^{59}$ Froebelian methods of teaching appear to have enjoyed particular support among radicals and nonconformists, especially the intellectual circle in Manchester based around Unitarianism, but involving many Germans and German Jews. This was also a circle with which Bunsen had close contacts, and the Bunsens, Schwabes and Cobdens corresponded and travelled round

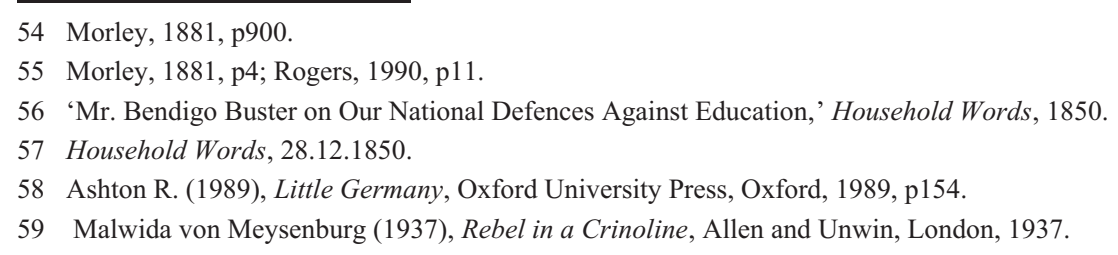


Europe together frequently ${ }^{60}$ This Germanic Manchester circle was boosted by the arrival of German political refugees after 1849, many of whom sought work as tutors. Cobden was in touch with several, including the radical professor Gottfried Kinkel. ${ }^{61}$

It is no surprise, therefore, that even before he was sent to Heidelberg, Dick Cobden spent his first school years at a German-run establishment in England. Cobden and Kate's correspondence testifies to the great deal of consideration that went into their son's schooling. At the beginning of 1850, Cobden announced to his brother Frederick that "we have arranged to send Richard to Dr Heldenmaier's school at Worksop...It is a well-conducted establishment, on the Pestalozzi plan, combining the training of a home, with good practical and modern tuition." ${ }^{, 62}$ Kate Cobden was possibly even more taken with German educational methods than her husband. In December 1850 Dr Heldenmaier sent her, along with details of the Christmas holidays, a memoir by Pestalozzi. ${ }^{63}$ When Dick's schooling turned out not to be successful, Cobden did not turn against the system. Rather, he reminded his son to "Recollect that the character of Dr Heldenmaier's school is very well established. Hundreds of young men who are reputable and thriving members of society, have been educated at his school. If you do not make good progress there, it will be attributed to your fault. Your character for life will be injured. It will be in vain for you to complain of the school. Dr Heldenmaier can appeal to thirty years of success in his profession and to the hundreds of men who have been educated by him, and who speak well of his school." $" 64$

In 1855 Dr Heldenmaier retired and returned to Germany, and Cobden was forced to seek another school. Finding a suitable one appears to have been difficult, and it was perhaps natural, given his views on education, that he consulted Baron Bunsen on the matter. Bunsen had, by now, retired to Heidelberg. Yet he was known to have wide contacts, particularly in the world of education. Cobden and he also saw eye-to-eye on many subjects. On $30^{\text {th }}$ June 1855 Bunsen wrote to Cobden: "My dear Mr Cobden I thank you sincerely for having believed me when I told you, it would give me great pleasure to assist you in choosing a place for your son's education, and I am happy to say that I have since become acquainted with an Institution such as you require, and with a man such as you graphically designate in your letter. The Institution is the real Schule (or College of practical knowledge) and the man is Mr Bender, the Director. The School has 45 to 50 pupils, but Mr Bender's Brother (one of the Professors) takes 3 or 4 pupils into his house, for boarding and private tutorship, and one place is vacant... The system of instruction is excellent; exactly what you want. Greek is begun only at 15, and only taught for practical purposes, unless specially wished. Gymnastics, Bathing \&c, form an integral part of the education. The situation is beautiful - The new term begins 15 Oct." ${ }^{65}$

In specifying an education less based on Classics and resting on practicalities, Cobden shared the admiration of the mercantile and middle classes in Britain for Germany's secular and modern educational system. In August 1855 he took his son to the school at Weinheim, near Heidelberg, travelling via Calais and the Rhine. On 25 August he wrote to his wife that "Yesterday we left Baden-Baden for Weinheim where we arrived about 2, ordered dinner for 5 at the little comfortable hotel and then proceeded to the school where we spent the

60 See Baroness von Bunsen (1868): Christian Carl Josias von Bunsen, Aus seinen Briefen und nach eigener Erinnerungen geschildert, Leipzig, 1868, volume II.

61 Ashton, 1989, p154. See also Alter P. (1987), The Reluctant Patron. Science and the State in Britain, 1850-1920, Berg, Oxford, 1987, p37.

62 Rogers, 1990, p98.

63 Rogers, 1990, p99.

64 Rogers, 1990, p103.

65 Rogers, 1990, p106. 
afternoon and then after dinner joined them again till 9 o'clock. I saw them in school at study - at Gymnastics in the playground, and took supper with them....The boys rise at 5, take some bread and milk at 7 , dine at 12 , have a huge bit of bread and some fruit at 4 , and sup off meat, \&c at " past 7. The only faults I should find that they eat too often and get too much meat - ...Richard will of course be chiefly employed for some months in learning German, but he will necessarily be learning French at the same time...I could not imagine a place where there is greater kindness on all sides than is shewn to the boys...

Dick parted with me much better than I expected. If there was a tear he turned away and hid it..." ${ }^{66}$

Dick's letters home from Weinheim suggest his time there was happy. Despite longing for his parents, he was looked after in the holidays by the Schwabes, who were well acquainted with Bunsen, and were allowed to exercise a sort of right of guardianship over Cobden's son. One exchange is particularly noteworthy, however, in relation to the German-Jewish flavour of life in Manchester in which the Cobden's lived. At the start of 1856 Dick inquired of his mother "...Is it true that Mr Ellison is a Jew a boy from Frankfurt who is with us at Mr. Lambelet's says that he was at school with his son and that he knows very well that he is a Jew. The German schoolboys when they are angry with any one call him a Jew and nothing puts them in a greater rage than to call them Jews. They cry against persons they see in the streets if he or she has the least resemblance to a Jew. n England the boys seldom if ever bothered a boy of about my age who was a Jew, but here they are always teasing each other about it." ${ }^{, 67}$

Kate Cobden's reply, however, was that "Mr Ellison may have been a Jew for all we know - You know that we never trouble our heads about such matters in England - The Germans are as intolerant about the Jews as the Americans are about the poor Negroes. It is a great blot in the character of both Nations to be so intolerant. Don't you fall into that evil feeling - Should a boy say anything to you on the subject again tell him that God made both Jew and Christian - and that it is His Province to judge and not yours or his." 68

This exchange says much about the Cobdens' openmindedness, as well as the cosmopolitan merchant circles within which the Cobden's circulated.

Richard Cobden would not see his son alive again after leaving him in Germany. Dick Cobden's success at Weinheim made his sudden death at Easter, 1856, all the more tragic. It is doubtful that this loss coloured Cobden's opinions in any way of Germany. Cobden remained on the warmest terms with the Schwabes, as well as with Bunsen, until the end of his life.

66 Rogers, 1990, p108.

673 January 1856, Dick Cobden to Kate Cobden, Rogers, 1990, p110.

6821 January 1856, Kate Cobden to Dick Cobden, Rogers, 1990, p110. 


\title{
Richard Cobden, the German States and the Zollverein
}

\section{John R. Davis}

\begin{abstract}
Richard Cobden was one of the main representatives of economic liberalism in the 19th century. He put through the fundamental changes in British economic policy which helped Great Britain become the strongest economic state in the world during the 19th century. The author concentrates on the analysis understanding and perception of the German Lands in the work of Richard Cobden. On the basis of Cobden's diary entries he gives attention not only to British-German economic relations but also for example to the comparison of school systems in which the German one's apprehended as more modern than the British one. Cobden went to the German Lands reveral times and he can be considered one of the main supporters of British-German co-operation in the 19th century.
\end{abstract}

Key words: Free Trade; Great Britain; Germany; Prussia; German Zollverein

\section{Richard Cobden, německé státy a Celní spolek}

\begin{abstract}
Abstrakt
Richard Cobden náležel k hlavním představitelům ekonomického liberalismu v 19. století. Zasadil se o zásadní změny v britské hospodářské politice, které napomohly tomu, že se Velká Británie stala nejsilnější ekonomickou zemí světa v 19. století. Autor se soustředil na analýzu chápání a vnímání německých zemí v díle Richarda Cobdena. Na základě jeho deníkových zápisků autor nevěnuje pozornost jen britsko-německým hospodářským vztahům, ale velký prostor věnuje také srovnání např. školských systémů, kdy se německý jevil jako moderní vůči zkostnatělému britskému. Cobden jezdil do Německa velmi často a patřil $\mathrm{k}$ hlavním přívržencům britsko-německé spolupráce v 19. století.
\end{abstract}

Klíčová slova: svobodný obchod; Velká Británie; Německo; Prusko; Německý celní spolek. 